Article

\title{
Recognising Effective Legal Protection to People Smuggled at Sea, by Reviewing the EU Legal Framework on Human Trafficking and Solidarity between Member States
}

\author{
Matilde Ventrella \\ School of Law, University of Wolverhampton, WV1 1LY, Wolverhampton, UK; E-Mail: Matilde.Ventrella@wlv.ac.uk
}

Submitted: 25 August 2014 | In Revised Form: 18 November 2014 | Accepted: 19 November 2014 |

Published: 23 February 2015

\begin{abstract}
The death toll of migrants at sea is on the increase. The EU and its Member States are not addressing the situation by widening the EU legal framework on human trafficking to persons smuggled at sea. People smuggled at sea are extremely vulnerable at the hands of their smugglers and suffer serious abuse of their human rights from their journeys through the desert, on the boats and when they reach their final destination. They become victims of human trafficking and they should not be neglected anymore by the EU and its Member States. However, all EU proposals lack of concreteness as Member States do not want to support and host migrants at sea on their territories. They are reluctant to launch solidarity between each other as requested by the Lisbon Treaty and by doing this, they are indirectly responsible for the death of many migrants at sea and for the abuse of their human rights. This article proposes alternatives to explore that could change the situation if Member States show their willingness to cooperate with each other.
\end{abstract}

\section{Keywords}

economic migrants; human rights; human trafficking; slavery: smuggling by sea

\section{Issue}

This article is part of the special issue "Perspectives on Human Trafficking and Modern Forms of Slavery", edited by Siddharth Kara (Harvard Kennedy School of Government, USA).

(C) 2015 by the author; licensee Cogitatio (Lisbon, Portugal). This article is licensed under a Creative Commons Attribution 4.0 International License (CC BY).

\section{The Extent of Smuggling of Migrants by Sea}

Smuggling of migrants by sea is a crime which is causing the death of many migrants. Migrants smuggled at sea are either genuine asylum seekers or unauthorized labour migrants (Fargues, 2014). Asylum seekers are eligible refugees whilst unauthorized labour migrants or economic migrants are not entitled to asylum unless they are victims of human trafficking. This article analyses international legislation and EU law on smuggling of migrants by sea and it argues that victims of smuggling of migrants by sea should be considered victims of human trafficking and granted the same legal protection as these victims. This is because victims of smuggling are vulnerable migrants who leave their countries of origin to avoid death because of famine, disease and poverty. Consequently, although they are not forced by criminals to leave their countries of origin, they do this because the alternative would be living in extreme poor conditions in their countries of origin. Their exact number is unknown because there is no reliable data on the reasons why they leave their countries of origin (Fargues \& Bonfanti, 2014).

International law and EU law have distinguished smuggling of migrants from human trafficking and, by doing this, they have allowed nations to prioritize border security rather than victims' protection. Consequently, all law addressing smuggling of migrants by sea at international, EU and national level, have concentrated on border controls when people smuggled by sea should have been legally protected as victims of human trafficking. This is because they are exposed to risk of death. It 
was recently reported that around five-hundred migrants smuggled by sea, including infants (ANSA, 2014), have drowned in the Mediterranean sea and others are dying and will continue to die if the EU does not adopt appropriate legislation to protect people smuggled by sea.

This article will show that trafficking and smuggling are linked with each other because, often, people smuggled by sea cannot repay the price for their journey to smugglers and for this reason they eventually become victims of human trafficking. Traffickers take an advantage of their poor situation to recruit them in forced labour and sexual activities. This is why they should be granted legal protection. Returning economic migrants should be a last resort in the EU as alternatives to their return should be explored. The EU should reform law on smuggling of migrants by sea promptly because in the Mediterranean Sea the situation is increasingly dramatic. Many migrants coming from Africa, especially from the Horn of Africa are drowning while they are trying to reach the EU through Italy. The accident of October 2013 beside the Italian island of Lampedusa where 366 migrants died, have shown the extent of the problem. Frontex has published data on the number of people crossing the Mediterranean by sea. In 2012, the number of migrants arriving in Europe irregularly across the Mediterranean has dramatically decreased from 141,051 in 2011 to 72,437 (Frontex, 2013; Manrique Gil, Barna, Hakala, Rey, \& Claros, 2014). However, in 2013, the number of irregular migrants crossing the Mediterranean sea from Africa, increased sharply and reached the number of 107,365 (Frontex, 2014a), because of the war in Syria, Iraq and the destabilizing situation in the Horn of Africa (Fargues, 2014).

When migrants at sea were interviewed, they stressed that they left their countries of origin because of insecurity and economic concerns (Frontex, 2014a). In addition, Somalis and Eritreans stated they used the route from Sudan and Ethiopia to reach the EU through the Central Mediterranean route, specifically Italy and Malta. ${ }^{1}$ In between migrants detected in the Central Mediterranean route, there were also Syrians who were leaving their country because of war (Frontex, 2014a). According to Frontex, the Central Mediterranean route particularly from North Africa to Italy, has accounted for $38 \%$ of all detection of irregular migrants at EU level (Frontex, 2014b). People from Horn of Africa have used the route from Libya and Tunisia to reach Italy and this route has seen episodic surges in migrant flows during the past ten years (Manrique Gil et al., 2014, supra note 4, p. 6). These data have been confirmed by the UNHCR which stated, in their most recent report, that the Central Mediterranean route received the majority of sea arrivals in 2013 with a dramatic increase compared to the previous year (United Nations High Commissioner for Refugees [UNHCR], 2013). In addition, Frontex has

${ }^{1}$ See in particular Table 6 of Frontex (2014, p. 31). reported that most people coming from the Horn of Africa use dangerous routes across the Sahara to reach Libya, prior to embarkation to Italy (Frontex, 2014a). They cross the Saharan desert (Frontex, 2014a) and many of them die in the desert and the survivors often report that they have to cross the borders of different countries at night time and, during these journeys, they spend much time without food, water or a shelter.

Subsequently, criminal organizations recruit migrants in the desert and support them in their difficult journeys. These organizations are usually hierarchically structured. In the organizations, there are intermediaries and brokers and the latter might be the only contacts migrants have with smugglers. This fact makes migrants very vulnerable as they have no other choice than trusting brokers (United Nations Office on Drugs and Crime [UNODC], 2014). Brokers and other intermediaries might be of the same ethno-linguistic background of migrants or they can be people who have become affiliated to smugglers after an unsuccessful sea-crossing they want to attempt again by earning money to pay smugglers for their journeys. Therefore, they have to work for smugglers until they gain enough money to try crossing the Mediterranean Sea again (UNODC, 2014). Brokers can also be nationals of migrants who have developed a very profitable business and may have no interest in crossing the sea. They liaise with middlemen who subsequently create a contact between migrants and smugglers and may be guarantors of payments by keeping the money until the journeys have been completed (UNODC, 2014). Smugglers might also promote their services to migrants through people who act as recruiters. Usually, recruiters work independently as they are not stranded to smugglers. They come from countries of origin of migrants or from transit countries (UNODC, 2014). Other people involved with smuggling at sea are transporters who accompany migrants from one country to another until the point of embarkation. There are then, people who pilot the boat who might not be aware of migration or people smuggling issues, including the involvement of criminal organisations (UNODC, 2014). They are usually fishermen who, because of their skills, are recruited by smugglers to transport migrants from one coast to another. Spotters provide specific information on controls at the borders and, in some occasions, sailors of commercial boats in the world, have informed smugglers about possible surveillance at the borders (UNODC, 2014). Research has suggested that corrupted officials in States, even of very high level such as border officials, police, immigration officials, soldiers and employees of embassies can participate in the smuggling of migrants at sea. They can be involved as organizers or facilitators (UNODC, 2011a). Migrants take weeks, months and even years to reach the Italian coast as their money run out and they cannot pay the price for their trips to the smugglers to reach Italy or other EU Mediterranean countries. Therefore, whilst waiting for embarkation, 
migrants can be threatened by enforcers who use violence in order to keep them under control or to make sure they pay the price for their journey. Many smuggled migrants have testified in Lampedusa that in Libya they are abused, tortured and raped (De Bruycker, Di Bartolomeo, \& Fargues, 2013). Testimonies of migrants have also reported that they work in Libya for sometimes in order to pay smugglers for their embarkation. Migrants at sea can pay their smugglers in different ways. One way is up front before departure; the second way is en route to the different smugglers involved or by credit. This latter method of payment often leads to human trafficking as the trip by boat is paid in advance by a third party but when migrants reach the countries of destination, they become victims of human trafficking because they are unable to repay the price for their trip (Papanicolopulu, 2013, p. 158; also, The Global Initiative, 2014; The International Organization for Migration and People Smuggling, 2011; United Nations Department of Economic and Social, 2013). These facts have also been confirmed by Interpol, which has published the result of evidence showing that smugglers continue to exploit migrants in the country of destination in order to obtain additional fees for their journeys (Interpol, n.d.). Furthermore, recent research undertaken by Italian journalists has found out that people smuggled by sea are often victims of traffic of organs since, when they cannot repay the price for their journey, they are left with no choice other than selling their kidneys and even corneas to smugglers (Attianese, 2014). Do migrants at sea make a free choice to leave their countries of origin and accept to be recruited by smugglers? They are tortured, raped and eventually become victims of human trafficking and removal of organs. Would they travel by the support of criminal organizations if they had other alternatives? It is thought that no people would travel in these conditions if they had other alternatives. Consequently, one can strongly affirm that they, as victims of human trafficking, are forced migrants and should be protected by the law which protects victims of trafficking.

For this purpose, international law and EU law on smuggling and trafficking should be reviewed. Finally, in the EU, smuggling of migrants by sea should be considered a form of human trafficking and the laws on these two crimes should belong to the same legal framework.

\section{Legal Framework of Human Trafficking and People Smuggling and the Recognition of Some Forms of Protection up to People Smuggled by Sea}

\subsection{Legal Framework of Human Trafficking and People Smuggling in International Law and in the EU Law}

At international level, assisting irregular migration is considered a crime by the Protocol against the Smuggling of Migrants by Land, Sea and Air, supplementing the United Nations Convention against Transnational
Organized Crime (UNTOC) (United Nations, 2001a) (from now on Smuggling Protocol). The Smuggling Protocol states that smuggling of migrants is the procurement of an illegal entry for a financial gain (United Nations, 2001a, art. 3). The Smuggling Protocol, although states that migrants shall not be prosecuted for having been the object of smuggling, does not recognize the fact that migrants can be coerced to leave their countries of origin because of their economic desperate conditions (United Nations, 2001a, art. 5). The Smuggling Protocol states that smuggled migrants have to be protected against violence of individuals and of criminal groups. Their rights to life and not to be subject to inhuman and degrading treatment must also be protected, although eventually smuggled migrants have to be returned to their countries of origin (United Nations, 2001a, art. 16 and 18). By comparing the UNTOC Smuggling Protocol with the UNTOC Trafficking Protocol, it could be noted that the differences between the two crimes are coercion and other forms of physical and psychological violence which are essential elements for the crime of trafficking in human beings but not for smuggling of migrants (United Nations, 2001b). The Smuggling Protocol focuses on the protection of fundamental rights of smuggled migrants (UNODC, 2011b) but not on the fact that they might be considered victims of poor circumstances and thus, deserving legal protection on the territory of the country of destination.

At European level, the situation is not different. Human trafficking and smuggling of migrants by sea do not belong to the same legal framework. Smuggling of migrants is considered a crime by the Facilitation Directive and its accompanying Framework Decision establishing effective, dissuasive and proportionate criminal penalties against people who assist irregular migration for financial gain (Council of the European Union, 2002a, 2002b). Some legal protection is granted to people smuggled by the Framework Decision which states that its provisions must be applied in compliance with the 1951 Refugee Convention and New York Protocol of 1967. In other terms, the Framework Decision has to take into consideration the right of nonrefoulment granted to refugees and asylum seekers (Council of the European Union, 2002a, Art. 6). In addition, the fight against smuggling of migrants cannot jeopardize the rights of migrants in need of subsidiary protection. Specifically, the fight against smuggling of migrants have to take into consideration the recast $\mathrm{Di}$ rective 2011 which has replaced Directive 2004/83/EC on the minimum standards for the qualification of subsidiary protection (European Parliament \& Council of the European Union, 2011b). ${ }^{2}$

\footnotetext{
2 The UK and Ireland are not bound by the recast Directive (see paragraph 50 of European Parliament, \& Council of the European Union (2004)). Therefore, these two Member
} 
Trafficking in human beings is dealt with the Council of Europe Convention on Action against Trafficking in Human Beings which regulates this crime (Council of Europe, 2005, Art. 4). The definition of human trafficking given by the Council of Europe Convention, is identical to the definition given by the UNTOC Trafficking Protocol. At EU level then, there is Directive 2011/36/EU which has replaced the Framework Decision 2002/629/JHA on human trafficking (European Parliament \& Council of the European Union, 2011a). The Trafficking Directive defines the crime and it establishes a very detailed programme for the protection of human trafficking victims' (European Parliament \& Council of the European Union, 2011a, Art. 1 and 11-16). The Directive, compared to the previous Framework Decision, is more specific in providing protection to victims of human trafficking. There are specific Articles in the Directive establishing the form of protection victims of human trafficking are entitled to and there is a particular attention given to children. Conversely, the Framework Decision had only one provision on the protection of victims as it prioritized the fighting against trafficking rather than the protection of victims (Council of the European Union, 2002c). Compared to the Council of Europe Convention, the Directive is more detailed as it defines the concept of vulnerability as "a situation in which the person concerned has no real or acceptable alternative but to submit to the abuse involved" (European Parliament \& Council of the European Union, 2011a, Art. 2(2)).

Although the EU legal framework on trafficking and smuggling is not the same, there are common provisions which apply to victims of these two crimes. These provisions can be found in Directive 2004/81/EC which entitles victims of these two crimes, to a residence permit (European Council, 2004). However, whilst granting a residence permit to victims of human trafficking is compulsory, it is discretionary, in the case of victims of people smuggling. This means that the application of the Directive to victims of people smuggling is not compulsory as the Directive leaves the decision on the protection of people smuggled to the hosting Member States (European Council, 2004, Art. 3). On the contrary, the people smuggled by sea should be recognized as vulnerable irregular migrants deserving legal protection because they leave their countries of origin forced by their economic situation. Unfortunately, economic and social poor situations are not considered enough elements to grant legal protection to victims of people smuggling by sea at the same level of victims of human trafficking (Bett, 2010).

\subsection{Prohibition of Collective Expulsion}

There are other rights recognised to smuggled migrants

States continue to be bound by European Parliament, \& Council of the European Union (2004, para. 38 and 39). by sea but their effectiveness is marginal because they do not contribute to reduce the death toll of migrants at sea. These rights are recognised by Article 4 Protocol 4 of the Convention for the Protection of Human Rights and Fundamental freedoms (ECHR) (Council of Europe, 1963, Art. 4, Protocol no. 4) and the related case-law of the European Court of Human Rights (ECtHR). On the basis of Article 4, the ECtHR has ruled in Becker v. Denmark (1975) that aliens cannot be pushed back without a "reasonable and objective examination of the particular cases of each individual alien of the group". This ruling has been confirmed by other cases such as Conka $\mathrm{v}$. Belgium (2002) where the ECtHR ruled that there was a violation of Article 4 Protocol 4 of the ECHR (Council of Europe, 1963) (prohibition of collective expulsion) because the personal situation and circumstances of individuals concerned had not been fully examined. Indeed, migrants were all requested to attend the police station at the same time and they were all requested to leave the Belgian territory at the same time. These facts were considered by the ECtHR as collective expulsion because the individual situations had not been considered separately and on a case by case basis.

Recently, an important decision has also been taken in Hirsi and others v. Italy (2012) where, for the first time, the ECtHR ruled that irregular migrants rescued in the extraterritorial sea, are under the control of the rescuing State and for this reason the prohibition of collective expulsion, applies also in this situation. In this case, Italian authorities pushed back to Libya a group of Eritreans and Somali. The Italian government stated that the push-back was the result of an agreement with Libya on return policy of irregular migrants intercepted at the sea. They also argued that the interception of migrants was done in the high sea and not in the national jurisdiction. Consequently, the Italian government did not have the full and exclusive control of migrants, thus, there was not collective expulsion prohibited by Article 4 Protocol 4. However, the ECtHR ruled that the applicants had fallen within the jurisdiction of the Italian State because in between the period of boarding the ship with migrants rescued the high sea and the period of handing them over the Libyan authorities, migrants had been under the continuous and exclusive control of the Italian authorities. The ECtHR ruled that the notions of expulsion and jurisdiction are territorial and therefore, Article 4 only prohibits collective expulsion committed on the national territory. Nevertheless, in this particular situation, the Italian government had exceptionally exercised extraterritorial jurisdiction and, thus, extraterritorial expulsion by sending migrants back to Libya whilst rescuing them at the high sea. Certainly, the ECtHR stated that States have the right to adopt a restrictive immigration policy with the aim to prevent irregular migration. However, this policy can be exercised only in respect of the Convention by not allowing collective expulsion and by giv- 
ing migrants the right to appeal against the expulsion decision. They should also be recognised an effective remedy as established by Article 13 ECHR. These rules also include restrictive policy applied extraterritorially. Indeed, they must be respectful of the prohibition of collective expulsion and of the right to grant an effective remedy no matter if policy has been implemented outside the national territory. In this situation, the Italian government had transferred the applicants to Libya without carrying out any examination of each individual situation. Immigrants have been embarked on ships, sent to Libya and disembarked there without considering their situation and their right to an effective remedy. Therefore, this action amounted to collective expulsion which is prohibited by Article 4 Protocol 4 of the ECHR and it was also in breach of Article $13 \mathrm{ECHR}$.

\subsection{Rights to Be Rescued and Disembarked}

International law is not clear about the place of disembarkation as the International Convention on Maritime Search and Rescue (SAR) only states that a person must be disembarked to a "place of safety" but where is the place of safety in EU Member States? (International Maritime Organization, 1979, chapter 1.3.2; also, De Bruycker et al., 2013). The SAR Convention has been amended in 2004 but the issue has not been resolved as it establishes that States have to agree the place for disembarking distressed people at sea ((International Maritime Organization, 1979, chapter 3.1.6.4). At EU level, instead, the Council and the Parliament have adopted a Regulation (Regulation 656/2014) which establishes new rules on maritime surveillance and rescue operations coordinated by Frontex (Council of the European Union, 2014). ${ }^{3}$ The new Regulation clearly prohibits collective expulsion (Council of the European Union, 2014, art. 4 (3)). ${ }^{4}$ The Regulation emphasizes that EU immigration and asylum policies should be based on the principle of solidarity in respect of Article 80 of the Treaty on the Functioning of the European Union (TFEU) (Council of the European Union, 2014, para. 2). Principle of solidarity means that all Member States shall share responsibility in order to implement the EU policies, including policies on asylum and immigration. This is a very positive element of the Regulation as it prioritizes cooperation between EU Member States when facing smuggling of migrants by sea. The Regulation introduces new interception and rescuing rules in order to protect migrants at sea more effectively and gives them the opportunity to disembark while waiting on a decision on their particular case. The Regulation addresses smuggling of migrants by estab-

\footnotetext{
${ }^{3}$ The UK and Ireland are not bound by this Regulation (para. 25 and 26).

${ }^{4}$ The article 4 (3) states that the personal circumstances of people rescued in the sea, must be assessed.
}

lishing specific rules when one Member State suspects that one vessel is engaged in the smuggling of migrants by sea (Council of the European Union, 2014, art. 6-7). For this purpose, the Regulation introduces new rules on the interception of migrants in the territorial sea, on the high seas and in the contiguous zone (Council of the European Union, 2014, art. 6-10).

However, these legal measures which strengthen rules on rescue operations, are not sufficient to prevent the death of irregular migrants smuggled by sea. A wider policy should be adopted to prevent their death. Rescuing and then returning migrants who cannot be considered victims of human trafficking, will not prevent the death of migrants at sea. These people are vulnerable migrants and no legal measures will only be effective until the concept of vulnerable migrants will be widened to include migrants smuggled by sea. In order to achieve this objective, the current EU legal framework on human trafficking should be reformed.

\section{Widening the Concepts of Vulnerability and Exploitation to Protect Migrants at Sea}

In international law, "People seem to occupy a space so small that it can be compared to that of a rock or a small island..." (Papanicolopulu, 2013, p. 194). There are no provisions establishing that States are legally obliged to protect individuals and their rights at sea ( $p$. 195). Certainly, as Papanicolopulu, points out, the UNTOC Smuggling Protocol obliges States to criminalise and fight against people smuggling (p. 198). However, victims of this crime committed at sea, are not considered individuals deserving legal protection at the same level of refugees or victims of human trafficking. This is why EU law should widen the concepts of vulnerability and exploitation to include people smuggled at sea.

On the basis of what it has been explained above (see Section 1), migrants at sea are forced migrants and, thus, exploited by their smugglers and, for this reason, they should be considered presumed victims. According to Eurostat, presumed victims are those people who have met the criteria to be identified as victims on the basis of Directive 2011/36/EU but who have not been formally identified by relevant authorities or who have refused to be identified as such (Eurostat Statistical, 2014). Migrants at sea could be considered presumed victims as, they are forced to leave their countries of origin because of extreme poverty and eventually, they are abused and exploited by smugglers. These criminals take an advantage of their conditions of extreme poverty for a financial gain, by endangering the lives of migrants in the desert and during their journeys to the EU. Indeed, smugglers do not hesitate to organize dangerous trips or to carry migrants on unsafe boats which sink very often in the Mediterranean. However, migrants at sea are not recognised as victims by relevant authorities of EU Mem- 
ber States because those authorities consider them irregular migrants with no rights of residence, apart from the right not to be collectively expelled and the right to be rescued at the sea. Directive 2011/36/EU does not expressly include smuggling of migrants at sea in its scope. It is strongly desirable, that Article 2 (1), (2) and (3) of the Directive is amended. Article 2 (1) states that trafficking in human beings is

"the recruitment, transportation, transfer, harbouring or reception of persons,...by means of the threat or use of force or other forms of coercion,... of a position of vulnerability...for the purpose of exploitation".

Forms of coercion include the abuse of a position of vulnerability which, according to Article 2(2) "means a situation in which the person concerned has no real or acceptable alternative but to submit to the abuse involved". It is thought that this is the position of people smuggled at sea as they are so desperate as not to have other alternative than accepting to be recruited by smugglers. It is desirable Article 2(1) specifies that the concept of vulnerability shall include vulnerable people recruited in the desert for the purpose of smuggling at sea. In this way the scope of the human trafficking's definition will be widened without any misinterpretation and Member States will be legally obliged to consider people smuggled by sea at the same level of victims of human trafficking.

However, human trafficking also includes the recruitment for the purpose of exploitation. Article 2(3) states that:

"Exploitation shall include, as a minimum, the exploitation of prostitution of others or other forms of sexual exploitation, forced labour or services, including begging, slavery or practices similar to slavery, servitude, or the exploitation of criminal activities, or the removal of organs".

Could migrants at sea be considered recruited for the purpose of exploitation? It is thought that they should be because migrants at sea suffer serious abuses of human rights when they are recruited by smugglers in the desert. They are abused, tortured and raped by smugglers in order to keep them under their control and ensure that they repay the price for their journey (see Section 1). These abuses can be compared to slavery or practices similar to slavery which are contemplated by Article 2 (3) of the Directive on human trafficking. According to the International Criminal Tribunal for the former Yugoslavia (ICTY), indications of enslavements could be the vulnerable position of a victim and other elements such as "psychological oppression or socio-economic conditions" (Prosecutor v. Kunarac, Kovac and Vukovic, 2001, para. 542). The ICTY was referring to the crime committed during a war (Pi- otrowicz, 2012, p. 184). However, the same concepts could be extended to people smuggled by sea because of their vulnerable socio-economic conditions. Indeed, they are forced to suffer abuses of their human rights such as rape and torture which smugglers practice on them without any respect for their human dignity. From one side, migrants at sea cannot avoid these abuses as they depend on smugglers' support without which, they would not be able to travel to the EU by sea. From the other side, smugglers exploit the vulnerability of migrants at sea and reduce them to a condition similar to slavery, in order to ensure they obtain a financial gain from the victims. This practice could be considered a form of slavery and within the scope of Article 2 (3) of Directive 2011/36/EU. This paragraph should be changed and it should state that slavery includes the abuses that smugglers at sea commit on migrants during their trips, before their embarkation and whilst their journey in the sea. This is because it has been reported that often migrants on the boats, are thrown into the sea by physical force by their smugglers. ${ }^{5}$ These amendments are very important to provide legal protection to people smuggled at sea.

\section{Protection of People Smuggled by Sea by Considering Them Potential Victims of Human Trafficking}

On the basis of the mid-term report on the EU strategy towards the eradication of human trafficking published by the European Commission (Commission), people smuggled by sea could also be considered potential victims (and not only presumed victims) of human trafficking and deserving the same legal protection of these victims. The Commission has highlighted that the defeat of human trafficking requires early identification of victims who "cannot be effectively assisted and protected if they are not properly identified" (European Commission, 2014b). For this purpose, the Commission called on Member States to establish appropriate mechanisms to ensure that victims are identified at an earlier stage and that they are provided with adequate protection, assistance including legal assistance in criminal proceedings. The Commission published Guidelines for the identification of victims which are particularly addressed to border guards and consular services (European Commission, 2013b). The Guidelines emphasize that the early identification of victims should be a priority. In order to achieve this outcome, not only victims but also potential victims of human trafficking should be identified at an early stage. In this way, victims will be protected and supported and police and prosecution authorities will be in a better position to investigate and detect traffickers. There are two

${ }^{5}$ These news are reported nearly daily on Italian newspapers. See, for example, II Sole 24 Ore (2013). 
elements to be considered in these reports. The first one is that the crime can be better detected if victims are identified as they might start a programme of recovery and eventually report traffickers. The second element is that the Commission also considers as priorities the identification of potential victims and their legal protection. Indeed, the Commission in its mid-term report states that once victims, including potential victims as indicated by the Guidelines, are identified, they shall be entitled to residence permits, labour rights, access to justice and compensation on the basis of Directive 2011/36/EU and of Directive 2012/29/EU. Consequently, the Commission is widening the scope of the human trafficking legal framework as it states that victims are not only those people who have been identified as such, but also those people who can become victims because of their circumstances. On the basis of what explained above (see Section 1), people smuggled by sea can be considered potential victims of human trafficking as when they cannot repay the price for their journey they become victims of human trafficking, including removal of organs. The legal protection that should be granted to migrants at sea is a residence permit as established by Directive 2004/81/EC (European Council, 2004). However, Article 3 of Directive 2004/81/EC should be modified by establishing as compulsory the issue of a residence permit to victims of people smuggling by sea. At the moment, the Directive does not make it compulsory but it leaves the choice to Member States' discretion. Therefore, people smuggled by sea might (and not shall) be entitled to a reflection period and to the issue of a residence permit as established by Article 8 of the Directive. In this way, it will be difficult to identify potential victims and the crime of human trafficking will not be defeated. Instead, it is important to address the problem of trafficking and its roots because its eradication can be successfully achieved by defeating the connected crime of people smuggling by sea. Enlarging the concepts of vulnerability and exploitation, granting compulsory legal protection to migrants at sea, on the basis of Directive 2004/81/EC, are essential to make the global fight against trafficking in human beings, effective.

The Commission seems determined to address smuggling of migrants at sea. Indeed, in its recent Communication on the application of Directive 2004/81/EC, it identified the strict links between smuggling of migrants by sea and human trafficking (European Parliament \& Council of the European Union, 2014). The Commission stated that it intends to implement "the actions identified by the Task Force Mediterranean, set up in October 2013 with the aim of preventing the loss of migrants' lives at sea by, inter alia, stepping up the fight against migrants trafficking and smuggling". Therefore, the Commission calls for a Global Approach to Migration and Mobility (GAMM) by concentrating on different actions (European Commis- sion, 2013a). One action consists of cooperating with countries of transit and origin of migrants at sea in order to prevent them from attempting to enter the EU irregularly and by the support of criminal organizations. Another action should focus on resettlement as it is "an important mean by which persons in need of protection can arrive safely to the European Union without going on hazardous journeys over the Mediterranean" (European Commission, 2013b). In order to achieve this objective, it is important that the EU in cooperation with international organizations, facilitate voluntary return of migrants at sea to their countries of origin. In addition, EU Member States should resettle migrants and increase their quotas. The Commission encourages resettlement through the Union Resettlement Programme which will be supported by the EU funding available under the Asylum and Migration Fund and it could publish guidelines on a common approach to humanitarian permits/visas (European Commission, 2013b).

The Commission reports are full of good intentions. However, an effective policy on the protection of migrants at sea can be adopted only if Member States will collectively tackle the problem with responsibility. Unfortunately, the Commission has reported that Member States are issuing low numbers of residence permits in exchange for cooperation and, only in exceptional circumstances, the residence permit is issued beyond the willingness of victims to cooperate (European Commission, 2014b). The Commission is also concerned because it is unclear how Member States identify victims and potential victims and inform them of their rights "to initiate a recovery process and to reflect before deciding whether to cooperate with the authorities" (European Commission, 2014b). Indeed, in the legislation of Member States, it is not specified whether the information is provided to officially identified victims or also to presumed victims. It is thought that presumed victims should be given the information as it could be a way to give them the opportunity to escape from the traffickers and smugglers by starting a programme of recovery.

Are Member States willing to grant legal protection, residence permit and right related to it to people smuggled by sea? They could do that by implementing the principle of solidarity but they are not taking action in this direction.

\section{The Need to Apply the Principle of Solidarity in the EU}

The principle of solidarity is a legal obligation that Member States shall comply with as it is expressly established by the Treaty of Lisbon. Article 80 TFEU states that "the policies of the Union...shall be governed by the principle of solidarity and fair sharing of responsibility, including its financial implications, between the 
Member States". The European Commission has emphasized in the Stockholm program that the principle of solidarity should lead the Union and its Member States to establish a common immigration and asylum policy (European Commission, 2010). However, at the moment the principle of solidarity has not been put in place and this fact is demonstrated by the recent actions of EU Member States. During the Arab Spring, which caused a surge in the number of migrants from North Africa to Italy where 20.000 Tunisians landed by sea, the Italian government, in order to respond to the emergency, issued a temporary visa to people in need of humanitarian protection. This visa entitled the holder to free movement in EU countries. Italy was aware that most of them would have moved to France because of historical links, common language and the presence of a diaspora (De Bruycker et al., 2013, supra note 22). As a result, the French government issued a Circular which stated that residence and temporary permits issued by EU Member States to third country nationals were not valid on the French territory unless notified to the European Commission by the issuing Member State (Nascimbeni \& Di Pascale, 2011, p. 353). Furthermore, the other Member States proposed to reintroduce checks at the internal borders of the Schengen area (De Bruycker et al., 2013). These facts demonstrate that no solidarity exists between Member States. Solidarity established by Article 80, could lead to a more effective protection towards migrants at sea. Unfortunately, spite and revenge between EU Member States prevail rather than the protection of vulnerable migrants at sea which should have the priority in order to prevent their death in the sea. The fact that there is not solidarity within the EU has also been reported by the European Parliament (EP) which has revealed that the Dublin system has not facilitated more cooperation and solidarity between Member States. This system "is practically inoperative as a mechanism to govern the allocation of responsibility" (European Parliament, 2009). The EP's Reflection Note stated that

\begin{abstract}
"Member States seem bent on minimizing their responsibilities under Dublin, and the evidentiary difficulties posed by the Dublin criteria provide them with good opportunity to do so, to the detriment of the systems' effectiveness. The Dublin III Proposal, which maintains those very same criteria, would do little to improve this situation". ${ }^{6}$
\end{abstract}

Indeed, the new Dublin III Regulation adopted in 2013 (Council of the European Union, 2013) did not address the EP's concerns because it made "no significant attempt to rethink the fundamentals of the Dublin system, even though it had led to significant human rights

${ }^{6}$ See The European Parliament reflection Note on the Evaluation if the Dublin System and on the Dublin III Proposal, page 4. abuses" (Peers, forthcoming). No Member States want to take responsibility of migrants at sea otherwise they would have implement adequately the Dublin II and Dublin III Regulations. Conversely, Member States do not want to deal with the problem of migrants at sea. Italy in October 2013, after the drowning of 366 migrants beside the Italian island of Lampedusa, has launched the Mare Nostrum operation to respond to the humanitarian emergency caused by the exceptional surge of migrants from Africa (Fargues \& Bonfanti, 2014). The Mare Nostrum operation aimed to rescue migrants at sea before the boat sank. However, despite the Italian government by this operation has saved many migrants, it has not complied with the Dublin III Regulation as civil servants have not registered the number of migrants entering the Italian territory (Fargues \& Bonfanti, 2014; also Trincia, 2014). Research suggests that a number of migrants have moved to Northern Europe but many other migrants have become victims of human trafficking, as explained above (Fargues \& Bonfanti, 2014; also Section 1 of this article). From one side, Italy by not registering migrants, has breached the Dublin III Regulation because Article 13 of this Regulation requires that Member States register asylum seekers entering their territory. From the other side, Italy has contested that it is unfair that the burden of rescuing migrants at sea and giving them asylum should only be of one Member State's responsibility (Fargues \& Bonfanti, 2014). In any case, their concerns are not justified because research has shown that Member States which host more migrants and asylum seekers, are Germany, Sweden, the United Kingdom and Belgium. Mediterranean countries, except from France, do not host the migrants rescued at sea. Countries which host more asylum seekers, should be granted financial support by the EU. In this way they will be more able to host migrants at sea for longer periods and to apply the principle of solidarity (Fargues \& Bonfanti, 2014). In fact, Northern European countries have asserted that solidarity should be increased by granting financial support to the Member States which host distressed migrants rescued on the high sea. Unfortunately, these issues have not been addressed and in October 2014, Mare Nostrum operation will be replaced by an operation called Joint Operation Triton and led by Frontex. Frontex is a small agency which can only be successful if supported by Member States (Fargues \& Bonfanti, 2014; also European Commission, 2014a). However, their support will be difficult to achieve. Indeed, Northern European countries are skeptical about this Joint Operation as they are asserting that the Mare Nostrum operation has increased the number of irregular migrants at sea (Paci, 2014). Conversely, they believe that the prospect of being saved increases the departures. The Italian UNHCR spokeswoman Carlotta Sami, stated that there is no evidence that suggest this is happening. She also reported that rescue operations 
are insufficient to save people and that it would be better the EU reviewed its legal migration policy to decrease irregular migration at sea (Paci, 2014).

This is an objective that will be even more difficult to achieve as Member States are not keen to adopt a more liberal migration policy despite they are in need of unskilled workers. Indeed, it has been reported that low skilled migration allows native workers to be recruited in jobs requiring higher skills (Fargues, 2014). In addition, low skilled migrants save industries from collapse or stagnation caused by shortage of native workers. The need of unskilled workers will increase in the next twenty years (Fargues, 2014). Migrants smuggled by sea could be employed as unskilled workers and not returned to their countries of origin. Finally, it should be considered whether people smuggled by sea could be returned voluntarily and only in this latter case, should they be returned to their countries of origin. This is because migrants by sea are trapped in vicious circles since, not having any economic alternatives in their countries of origin, they will always try to leave them regularly. Nevertheless, if this is not possible because of EU strict policies on immigration, they will leave irregularly. The Ministry of Foreign Affairs in Senegal stated that the EU common approach to migration prioritizes control of external borders. Instead, an effective way to prevent migration could be adopted by creating more wealth in African countries (Reslow, 2012). If wealth is not created, there will always be people trying to leave their countries of origin to avoid death because of famine. These policies will be effective when Member States will work together by applying the principle of solidarity which at the moment is not being launched and it does not seem it will be launched in the next future.

\section{Conclusions}

This article has shown that migrants at sea do not have the same legal status of victims of human trafficking. The only rights recognized to them are the right not to suffer collective expulsion and the right to be rescued in the sea. Their specific situations have to be evaluated individually by hosting Member States because collective and automatic expulsion is prohibited by Article 4 of Protocol 4 ECHR. In addition, Member States have the legal obligation to rescue them in their territorial waters and in the contiguous international waters. However, they are not eligible to refugee and if they are not recognised victims of human trafficking, they will not have the right to be legally protected within EU Member States. They should be granted a visa on the same conditions of human trafficking victims'. In addition, if neglected, they will eventually become victims of human trafficking to repay the price of their journey to smugglers. Their effective protection could be guaranteed by reviewing the EU legal framework on human trafficking and by strengthening solidarity between Member States. However, the EU legal framework can only be reviewed if Member States cooperate with each other in rescuing and hosting migrants at sea. At the moment, there is not solidarity between Member States. They are blaming each other and are not showing concerns for migrants at sea. This is the reason why the situation is destined to further failure.

\section{Acknowledgements}

The author thanks Prof Steve Peers for his advice and help.

\section{Conflict of Interests}

The author declares no conflict of interests.

\section{References}

ANSA. (2014, August 8). Barcone affondato davanti coste Libia venerdi, oltre 250 morti. ANSA. Retrieved from http://www.ansa.it/sito/notizie/ cronaca/2014/08/24/nuova-tragedia-dei-migranti18-cadaveri-a-lampedusa_4112af3d-18ad-4a4ea01b-504776135c08.html

Attianese, L. (2014, November 1). Nuova frontiera del traffico d'organi. Africa take away. ANSA. Retrieved from http://www.ansa.it/sito/notizie/magazine/ numeri/2014/10/10/africa-take-away_9037661f41a5-4e68-9ebf-686a1486678c.html

Becker v. Denmark 1975 Application no. 7011/75.

Bett, A. (2010). Towards a "soft" law framework for the protection of vulnerable irregular migrants. International Journal of Refugee Law, 22(2), 209-236.

Conka v. Belgium ECHR 2002-I.

Council of Europe. (1963). Protocol no. 4 to the Convention for the Protection of Human Rights and Fundamental Freedoms, securing certain rights and freedoms other than those already included in the Convention and in the first Protocol thereto as amended by protocol no. 11. Strasbourg, France: Council of Europe. Retrieved from http://con ventions.coe.int/Treaty/en/Treaties/Html/046.htm

Council of Europe. (2005). Convention on action against trafficking in human beings. Strasbourg, France: Council of Europe. Retrieved from http://conventions.coe.int/Treaty/EN/Treaties/Htm I/197.htm

Council of the European Union. (2002a). Council Directive 2002/90/EC of 28 November 2002 defining the facilitation of unauthorised entry, transit and residence (Facilitation Directive) (OJ 2002 L 328 15/12/2002). Brussels, Belgium: Council of the European Union.

Council of the European Union. (2002b). Council Framework Decision 2002/946/JHA of 28 November 
2002 on the strengthening of the penal framework to prevent the facilitation of unauthorised entry, transit and residence (OJ L 328 15/12/2002). Brussels, Belgium: Council of the European Union.

Council of the European Union. (2013). Regulation (EU) No 604/2013 of the European Parliament and of the Council of 26 June 2013 establishing the criteria and mechanisms for determining the Member State responsible for examining an application for internal protection lodged in one of the Member States by a third-country national or a stateless person (recast) (OJ L. 180/31-180/59; 29.6.2013). Brussels, Belgium: Council of the European Union. Retrieved from http://www.refworld.org/docid/51d298f04.html

Council of the European Union. (2014). Regulation (EU) no 656/2014 of the European Parliament and the Council of 15 May 2014 establishing rules for the surveillance of the external sea borders in the context of operational cooperation coordinated by the European Agency for the Management of Operational Cooperation at the External Borders of the Member States of the European Union (L 189/93, 27/6/2014). Brussels, Belgium: Council of the European Union. Retrieved from http://eur-lex.europa. eu/legal-content/EN/TXT/PDF/?uri=CELEX:32014RO 656\&from $=E N$

Council of the European Union. (2002c). Council Framework decision of 19 July 2002 on combating trafficking in human beings. Retrieved from http://eur-lex.europa.eu/legal-content/EN/TXT/ PDF/?uri=CELEX:32002F0629\&from $=E N$

De Bruycker, P., Di Bartolomeo, A., \& Fargues, P. (2013). Migrants smuggled by sea to the EU: Facts, laws and policy options. San Domenico de Fiesole, Italy: Migration Policy Centre. Retrieved from http://www.migrationpolicycentre.eu/docs/MPCRR-2013-009.pdf

European Commission. (2010). Communication from the commission to the European Parliament, the Council, the European Economic and Social Committee and the Committee of the Regions. Delivering an area of freedom, security and justice for Europe's citizens. Action Plan Implementing the Stockholm Programme (COM(2010) 171 final). Brussels, Belgium: European Commission. Retrieved from http://eur-lex.europa.eu/LexUriServ/LexUriServ. do?uri=COM:2010:0171:FIN:en:PDF

European Commission. (2013a). Communication from the Commission to the European Parliament and the Council on the work of the Task Force Mediterranean (COM(2013) 869 final). Brussels, Belgium: European Commission. Retrieved from http:// ec.europa.eu/dgs/home-affairs/what-is-new/news/ news/docs/20131204_communication_on_the_wor k_of_the_task_force_mediterranean_en.pdf

European Commission. (2013b). Guidelines for the identification of victims of trafficking in human be- ings. Brussels, Belgium: European Commission. Retrieved from http://ec.europa.eu/dgs/home-affairs/ e-library/docs/thb-victims-identification/thb_identi fication_en.pdf

European Commission. (2014a). Frontex Joint Operation "Triton"-Concerted efforts to manage migration in the Central Mediterranean. Brussels, Belgium: European Commission. Retrieved from http://europa.eu/rapid/press-release_MEMO-14566_en.htm

European Commission. (2014b). Mid-term report on the implementation of the EU strategy towards the eradication of trafficking in human beings (Commission staff working document) (SWD(2014) 318 final). Brussels, Belgium: European Commission. Retrieved from http://ec.europa.eu/dgs/home-affairs/ what-is-new/news/news/docs/20141017_mid-term _report_on_the_2012-2016_eu_strategy_on_ trafficking_in_human_beings_en.pdf

European Council. (2004). Council Directive 2004/81/EC of 29 April 2004 on the residence permit issued to third-country nationals who are victims of trafficking in human beings or who have been the subjects of an action to facilitate illegal immigration, who cooperate with the competent authorities (OJ L 261, p. 19). Brussels, Belgium: European Council.

European Parliament. (2009). The European Parliament reflection note on the evaluation if the Dublin System and on the Dublin III Proposal. Strasbourg, France: European Parliament. Retrieved from http://www.europarl.europa.eu/RegData/etudes/n ote/join/2009/410690/IPOL-LIBE_NT\%282009\%294 10690_EN.pdf

European Parliament, \& Council of the European Union. (2004). Council Directive 2004/83/EC of 29 April 2004 on minimum standards for the qualification and status of third country nationals or stateless persons who otherwise need international protection and the content of the protection granted (OJ L 304 p. 12, 30/9/2004). Strasbourg, France: European Parliament. Retrieved from http://eurlex.europa.eu/legal-content/EN/TXT/PDF/?uri $=$ CELEX:32011L0095\&from $=e n$

European Parliament, \& Council of the European Union. (2011a). Council and European Parliament Directive 2011/36/EU of 5 April 2011 on preventing and combating trafficking in human beings and protecting its victims, and replacing Council Framework Decision (2002/629/JHA, OJ 101, p.1, 15/4/2011). Strasbourg, France: European Parliament. European Parliament, \& Council of the European Union. (2011b). Parliament and Council Directive 2011/95/EU of 13 December 2011 on standards for the qualification of third-country nationals or stateless persons as beneficiaries of international protection, for a uniform status for refugees or for persons eligible for subsidiary protection and for the content 
of the protection granted (OJ L 337 p. 9, 20/12/ 2011). Strasbourg, France: European Parliament.

European Parliament, \& Council of the European Union. (2014). Communication from the Commission to the Council and the European Parliament. On the application of Directive 2004/81 on the residence permit issued to third-country nationals who are victims of trafficking in human beings or who have been the subject of an action to facilitate illegal immigration, who cooperate with the competent authorities (COM(2014) 635 final). Strasbourg, France: European Parliament. Retrieved from http://ec.europa.eu/transparency/regdoc/rep/1/20 14/EN/1-2014-635-EN-F1-1.Pdf

Eurostat Statistical. (2014). Trafficking in human beings (Working papers). Luxembourg: European Union. Retrieved from http://ec.europa.eu/dgs/homeaffairs/what-is-new/news/news/docs/20141017_ working_paper_on_statistics_on_trafficking_in_ human_beings_en.pdf

Fargues, P. (2014). Is what we hear about migration really true? Fiesole, Italia: European University Institute. Retrieved from http://cadmus.eui.eu/bit stream/handle/1814/31731/MPC_2014_FARGUES. pdf?sequence $=1$

Fargues, P., \& Bonfanti, S. (2014). When the best option is a leaky boat: Why migrants risk their lives crossing the Mediterranean and what Europe is doing about it. Fiesole, Italia: European University Institute. Retrieved from http://cadmus.eui.eu/bit stream/handle/1814/33271/MPC_PB_2014-05.pdf ?sequence $=1$

Frontex. (2013). Annual risk analysis. Warsaw, Poland: Frontex. Retrieved from http://frontex.europa.eu/ assets/Publications/Risk_Analysis/Annual_Risk_ Analysis_2013.pdf

Frontex. (2014a). Annual risk analysis. Warsaw, Poland: Frontex. Retrieved from http://frontex.europa.eu/ assets/Publications/Risk_Analysis/Annual_Risk_ Analysis_2014.pdf

Frontex. (2014b). Frontex publishes annual risk analysis 2014. Frontex. Retrieved from http://frontex. europa.eu/news/frontex-publishes-annual-riskanalysis-2014-wc71Jn

Hirsi and others v. Italy 201255 EHRR 21.

II Sole 24 Ore. (2013, September 30). Ragusa, tredici migranti annegati. "Buttati a mare a colpi di bastone". II Sole 24 ore. Retrieved from http:// www.ilsole24ore.com/art/notizie/2013-09-30/tragi co-sbarco-migranti-ragusano-112523. shtml?uuid=A bMph3fl

International Maritime Organization. (1979). International Convention on Maritime Search and Rescue (SAR). London, UK: International Maritime Organization. Retrieved from http://www.imo.org/ About/Conventions/ListOfConventions/Pages/Inter national-Convention-on-Maritime-Search-and-
Rescue-\%28SAR\%29.aspx

Interpol. (n.d.). People smuggling. Retrieved from http://www.interpol.int/Crime-areas/Trafficking-inhuman-beings/People-smuggling

Manrique Gil, M., Barna, J., Hakala, P., Rey, B., \& Claros, E. (2014). Mediterranean flows into Europe: Migration and the EU's foreign policy. Strasbourg, France: European Parliament. Retrieved from http://www.europarl.europa.eu/RegData/etudes/b riefing_note/join/2014/522330/EXPO-

JOIN_SP(2014)522330_EN.pdf

Nascimbeni, B., \& Di Pascale, A. (2011). The "Arab spring" and the extraordinary influx of people who arrived in Italy from the North Africa. European Journal of Migration and Law, 13(4), 341-360.

Paci, F. (2014). La portavoce dell Unhcr: "I soccorsi non bastano più. L'UE consenta arrivi legali". Retrieved from http://www.lastampa.it/2014/09/16/italia/ cronache/la-portavoce-dellunhcr-i-soccorsi-non-bas tano-pi-lue-consenta-arrivi-legali-wL03IQpE5VYKpB 5NfkPg3L/pagina.html

Papanicolopulu, I. (2013). The Law of the Sea Convention: No place for persons? In D. Freestone (Ed.), The 1982 Law of the Sea Convention at 30: Successes, challenges and new agendas (pp. 193-200). Leiden, the Netherlands: Martinus Nijhoff Publishers.

Peers, S. (forthcoming). The Dublin III Regulation. In S. Peers \& E. Guild (Eds.), EU Immigration and Asylum Law: Text and commentary (Vol. 3, 2nd edition, Chapter 6). Martinus Nijhoff Publisher.

Piotrowicz, R. (2012). States' obligations under human rights towards victims of trafficking in human beings: Positive developments in positive obligations. International Journal of Refugee Law, 24(2), 181201.

Prosecutor v. Kunarac, Kovac and Vukovic 2001 Case No. IT-96-23-T.

Reslow, N. (2012). The role of third countries in EU migration policy: The mobility partnership. European Journal of Migration and Law, 14(4), 393-415.

The Global Initiative. (2014). Smuggled futures: The dangerous path of a migrant from Africa to Europe. New York, NY: The Global Initiative. Retrieved from http://www.globalinitiative.net/smuggled-futures/

The International Organization for Migration and People Smuggling. (2011). OM's immigration \& border management programmes. Geneva, Switzerland: The International Organization for Migration and People Smuggling. Retrieved from http://www. iom.int/jahia/webdav/shared/shared/mainsite/acti vities/ibm/10-IOM-IBM-FACT-SHEET-Peoplesmuggling.pdf

Trincia, P. (2014). L'odissea dei migranti. Servizio Publico. Retrieved from http://www.serviziopubblico.it/ 2014/05/lodissea-dei-migranti

United Nations Department of Economic and Social. (2013). Affairs international migration policies: 
Government views and priorities. New York, NY: United Nations. Retrieved from http://www.un. org/en/development/desa/population/publications /pdf/policy/InternationalMigrationPolicies2013/Re port\%20PDFs/k_Ch_5.pdf

United Nations High Commissioner for Refugees. (2013). UNHCR: Global report. Geneva, Switzerland: United Nations. Retrieved from http://www. unhcr.org/539809e10.html

United Nations Office on Drugs and Crime. (2011a). Issue paper: Smuggling of migrants by sea. Vienna, Austria: UNODC. Retrieved from http://www. unodc.org/documents/human-trafficking/MigrantSmuggling/Issue-Papers/Issue_Paper_Smuggling_of_Migrants_by_Sea.pdf

United Nations Office on Drugs and Crime. (2011b). Smuggling of migrants. A global review and annotated bibliography of recent publications. Vienna, Austria: UNODC. Retrieved from http://www. unodc.org/documents/human-trafficking/Migrant-
Smuggling/Smuggling_of_Migrants_A_Global_ Review.pdf

United Nations Office on Drugs and Crime. (2014). Smuggling of migrants: The harsh search for a better life. Vienna, Austria: UNODC. Retrieved from http://www.unodc.org/toc/en/crimes/migrantsmuggling.html

United Nations. (2001a).Protocol against the smuggling of migrants by land, sea and air, supplementing the United Nations Convention against Transnational Organized Crime A/RES/55/25, 8.1.2001 (Document A/55/383). New York, NY: United Nations.

United Nations. (2001b). Protocol to prevent, suppress and punish trafficking in persons, especially women and children, supplementing the United Nations Convention against Transnational Organized Crime. United Nations Convention against Transnational Organized Crime A/RES/55/25, 8.1.2001 (Document A/55/383). New York, NY: United Nations.

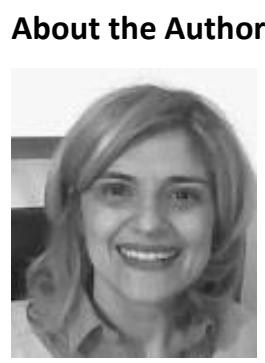

\section{Dr. Matilde Ventrella}

Dr. Matilde Ventrella is a Senior lecturer at the University of Wolverhampton (UK). She earned her Law Degree from the University of Bari (Italy), her LLM from the University of Dundee (UK) and her PhD from the University of Birmingham (UK). Her PhD thesis concentrated on smuggling of migrants and trafficking in human beings in the EU and it has been published by Ashgate in a book entitled The control of people smuggling and trafficking in the EU: Experiences from the UK and Italy. Dr. Ventrella is currently undertaking research on both short term and long term solutions against human trafficking. 